\title{
Effects of Prohexadione-Ca, Ethephon, and Water Stress on Growth and Productivity of 'Golden Delicious'/M.9 Apple
}

\author{
Sunghee Guak \\ Department of Horticulture, Chonbuk National University, Jeonju 561-756, Korea
}

\begin{abstract}
Prohexadione-calcium (Pro-Ca), ethephon and transient water stress were evaluated in a factorial design, as potential inhibitors of early-season shoot growth of high density orchard management of apple (Malus domestica Borkh.) trees. In the experiment, water stress was imposed to one-half of the 7-year-old 'Golden Delicious'/M.9 apple trees in each of 5 blocks, by stopping irrigation for 3 weeks between 35 and 56 days after full bloom (AFB). Within each whole unit, the following Pro-Ca and ethephon treatments were randomly allocated at $2 \times 2$ factorial: a) 0 or $250 \mathrm{mg} \cdot \mathrm{L}^{-1}$ a.i. Pro-Ca applied at 28 days AFB and b) 0 or $300 \mathrm{mg} \cdot \mathrm{L}^{-1}$ a.i. ethephon applied twice ( 35 and 71 days AFB). All trees were hand thinned to king flowers prior to treatments. Vegetative shoot growth was markedly reduced by Pro-Ca, with its effect being obvious within 14 days after application, while ethephon and water stress treatments were less effective. Pro-Ca had no effect on fruit set and yield but slightly increased fruit size. Ethephon substantially reduced the fruit size and yield but had no effect on fruit set. Water stress reduced fruit set, fruit size and yield. With regard to fruit quality, Pro-Ca did not influence fruit shape, flesh firmness and soluble solids contents (SSC) but slightly reduced titratable acidity. Ethephon had no effect on fruit shape but increased firmness, SSC and acidity, while water stress did not influence these fruit quality attributes. Dry weight of dormant spur buds was reduced by both Pro-Ca and water stress, while increased by ethephon. The larger dormant buds led to the larger spur flowers at the tight cluster stage the following spring. Return flowering was promoted only by ethephon, especially on previous season's shoots. There were no significant interactions between Pro-Ca and ethephon or water stress on most variables observed in this study.
\end{abstract}

Additional key words: fruit quality, fruit set, gibberellin biosynthesis inhibitor, return bloom, specific leaf weight, stomatal conductance, water potential

\section{Introduction}

In apple trees, an appropriate balance between vegetative growth and crop load is essential. Growth control is required for young apple trees to hasten flowering, while for bearing trees to prevent crowding and excessive shading. Frequently, management mistakes or abnormal weather conditions disrupt this delicate balance, resulting in excessive vegetative growth. If not appropriately controlled, this excessive growth negatively influences flower bud formation and fruit set, by causing shading or the early competition for stored resources.

Various nonchemical ways to control vegetative growth have been practiced, including use of dwarfing rootstocks, pruning and limb spreading. Although dwarfing rootstocks have been successfully used to control vegetative growth on apples, rootstock cannot be a sole solution because unanticipated events such as lack of crop resulting from frost or excessive thinning and biennial bearing tendencies may tip the balance in favor of vegetative growth. These situations require additional forms of growth control.

Gibberellic acids (GA) have often been implicated in both stem elongation and flower inhibition (Rademacher, 1991). As a result, inhibitors of GA-biosynthesis have been evaluated as tools for restricting vegetative growth or promoting floral initiation. Among those PGRs, paclobutrazol of a triazole group is most useful for this purpose (Quinlan and Richardson, 1984; Steffens et al., 1992). Chlormequat and daminozide are also well-known inhibitors of GA-biosynthesis. However,

\footnotetext{
*Corresponding author: guaks@chonbuk.ac.kr

※ Received 3 October 2012; Revised 16 November 2012; Accepted 21 November 2012. The author thanks Drs. N.E. Looney, D. Neilsen and G. Neilsen at Pacific Agri-Food Research Centre in Summerland, British Columbia Canada, for encouragement they have so generously provided by sharing their financial support, thoughts and facilities over the years. I also thank Michael Beulah for his capable assistance and Brian Drought for the analyses of mineral nutrients.
} 
these PBRs were withdrawn from the market because of their extended persistence in soil and trees, and public concern over their use (Greene, 1986).

Recently Prohexadione-calcium (Pro-Ca; Apogee ${ }^{\circledR}$ BASF Corp., Research Triangle Park, NC, USA), another GAbiosynthesis inhibitor with low toxicity and limited persistence, has been effectively used for controlling the vegetative growth on apples (Basak, 2004; Byers et al., 2004; Guak et al., 2001; Rademacher and Kober, 2003). The maximum growth control is achieved when the first application is made as soon as sufficient foliage has emerged to absorb the chemical - generally at petal fall when terminal shoot growth is between 2 and $7 \mathrm{~cm}$ (Miller, 2002; Rademacher et al., 2004). Although its mode of action has not yet been resolved, Pro-Ca is known to increase fruit set, with a corresponding decrease in fruit size and return bloom, especially when high rates, i.e. above $250 \mathrm{mg} \cdot \mathrm{L}^{-1}$ are used (Greene, 2008). To avoid these side effects, multiple applications using lower rates are recommended (Greene, 2008).

Only limited information is available on the physiological effects of Pro-Ca in apple trees. Pro-Ca increases nonstructural carbohydrates in shoots of 'Golden Delicious' nursery trees (Owens and Stover, 1999) and in leaves of M.26 rootstock liners (Guak et al., 2001). Pro-Ca reduces total area of leaves formed after treatment but increased specific leaf weight in M.26 rootstock liners (Guak et al., 2001). Glenn and Miller (2005) suggested that the photosynthetic efficiency may be improved on young, bearing apple leaves treated with Pro-Ca, via reduced leaf area (thus reduced shading) but unchanged rate of whole-canopy photosynthesis.

Ethephon is known to be effective in controlling the vegetative growth of young apple trees where there is a complete or partial crop loss resulting from frost (Byers, 1993) and of grape (Shulman et al., 1980) and young sweet cherry trees (Elfving et al., 2003). Ethephon applied shortly after bloom reduces shoot growth and increases flowering the next year (Elfving and Cline, 1990). However, ethephon applied postbloom at concentrations to control shoot growth and increase flowering often causes an excessive thinning in bearing trees (Byers, 1993; Edgerton and Greenhalgh, 1969). Combinations of GA-biosynthesis inhibitors such as daminozide and Pro-Ca plus ethephon increase flowering and cropping in apple and sweet cherry trees at lower concentrations of each material (Elfving and Cline, 1990; Elfving et al., 2003; Lord et al., 1975).

Vegetative growth can also sometimes be controlled by the manipulation of plant water status without significantly suppressing fruit growth (Caspari et al., 2004). Deficit irrigation strategies, such as regulated deficit irrigation (RDI) and partial root-zone drying (PRD), have been evaluated to determine the effects on water saving, vegetative growth, fruit quality and yield efficiency in apple (Caspari et al., 2004; Ebel et al., 1995) and more widely in grapes (Dry and Loveys, 1998). Unlike in grapes, RDI treatments readily reduced fruit size and yield in apple (Mpelasoka et al., 2000) while a PRD strategy had no effect (Caspari et al., 2004). The timing of ending water deficit treatments is important to prevent undesirable effects of water deficit on fruit quality and yield. In apple, water deficit practice is usually terminated before fruit growth declines below the standard curve (Ebel et al., 1995).

The objectives of this study were to control vegetative growth with Pro-Ca, ethephon and water stress alone and in combination, to relate the growth control effects to fruit set, fruit and tree nutrient levels and return bloom, and to investigate whether the efficacies of Pro-Ca and ethephon as growth inhibitors were influenced by water stress.

\section{Materials and Methods}

\section{Plant Material and Treatments}

This factorial experiment used 7-year-old 'Golden Delicious' /M.9 slender spindle apple (Malus domestica Borkh.) trees at $1 \mathrm{~m} \times 3 \mathrm{~m}$ spacing. The trees were fertigated with 150 $\mathrm{mg} \cdot \mathrm{L}^{-1} \mathrm{~N}$ as $\mathrm{Ca}\left(\mathrm{NO}_{3}\right)_{2}$ through atmometer-scheduled drip irrigation from petal fall to the end of July. In a split-plot randomized block design with five blocks and single tree per treatment per block, one-half of the trees in each block were deprived of fertigated water for 3 weeks from 35 to 56 days after full bloom (AFB). To exclude rain from no irrigation blocks, the ground was covered for $80 \mathrm{~cm}$ of each side along the trees, with black plastic film. Thus, whole units were 'water stress' treatments and received two buffer trees between units. Within each whole unit, the following PGR treatments were randomly allocated at $2 \times 2$ factorial: a) 0 or $250 \mathrm{mg} \cdot \mathrm{L}^{-1}$ a.i. Pro-Ca applied 28 days AFB; b) 0 or $300 \mathrm{mg} \cdot \mathrm{L}^{-1}$ a.i. ethephon $\left(\right.$ Ethrel $^{\circledR}$, Bayer CropScience, Research Triangle Park, NC, USA) applied twice (35 and 71 days AFB). Whole trees were sprayed to runoff with each PBR solution containing $0.1 \%(\mathrm{v} / \mathrm{v})$ of the nonionic surfactant ABG-7034 (Abbott Labs., Chicago, IL, USA), using a backpack sprayer.

\section{Growth Measurements}

Before treatments, all blossom clusters were counted on whole trees, and blossom intensity was expressed as the number of flowers per $\mathrm{cm}^{2}$ trunk cross-sectional area (TCSA). At pink stage, all blossom clusters were hand-thinned to king flowers. Total fruit set was determined following the June drop (52 days AFB) and was expressed as the number of 
king fruit per 100 counted flower clusters. Thereafter, all trees were hand-thinned to a commercial crop load. Shoot elongation growth was monitored at 7 to 10 days intervals from early June to late August, for two types of shoots, i.e. vigorously growing top shoots $(n=3)$ and more horizontally growing side shoots $(n=4)$. In the mid August when terminal buds were set, 15 leaves (three per shoot) per tree were randomly sampled from mid-shoot positions of current season's shoots to determine mean leaf area and specific leaf weight (mg DW per $\mathrm{cm}^{2}$ leaf area). After measurements of leaf area, leaf samples were oven-dried at $85^{\circ} \mathrm{C}$ for three days and dry matter was weighed.

\section{Leaf Water Potential and Stomatal Conductance}

Leaf water potential and stomatal conductance were measured on the mid-shoot leaves of mid-canopy shoots (2 leaves per tree) on the last day of water stress period and 9 days after re-irrigation. Measurements were made between 10:00 and 12:00 with a Sholander pressure chamber (PMS Instruments, Corvallis, OR, USA) and a LI-1600 steady-state porometer (LI-COR, Inc., Lincoln, NE, USA), respectively. To minimize the time-related errors, measurements were made for the first replicate in each tree throughout all treatments and then for the second replicate.

\section{Fruit Quality Attributes and Mineral Nutrients}

Fruit weight, fruit shape (L/D) and yield were determined at harvest, as well as fruit quality attributes and fruit nutrients for $\mathrm{N}, \mathrm{P}, \mathrm{K}, \mathrm{Ca}, \mathrm{Mg}$, and B. A 15-apple subsample collected at random from each tree at harvest was evaluated for flesh firmness, titratable acidity (TA) and soluble solids contents (SSC) using a pressure tester (EPT-1; Lake City Technical Products, Inc., Kelowna, British Columbia, Canada), a titrator (655 Dosimat; Metrohm Ltd., Herisau, Switzerland), and a refractometer (PR-101; Atago Co., Ltd., Tokyo, Japan), respectively. Firmness was determined on either sides of the fruit and TA was determined by recording the amount of $0.1 \mathrm{~N} \mathrm{NaOH}$ added to titrate $15 \mathrm{~mL}$ of juice to $\mathrm{pH}$ 8.1. These fruit quality attributes were also determined immediately after 40 days of cold storage and also after 7 days of ripening at the room temperature.

For analyses of fruit mineral nutrients, 10 fruits were randomly sampled from each tree and rinsed under running, distilled water and air-dried. Each fruit was cut longitudinally into quarters, and stems and seeds were removed. Two opposing quarters were pooled and blended with 1.5 times their mass of distilled water. A $150-\mathrm{mL}$ subsample aliquot of homogenized slurry was digested in 5.4-mL of concentrated $\mathrm{H}_{2} \mathrm{SO}_{4}$ containing $\mathrm{Na}_{2} \mathrm{SO}_{4}(1.8 \mathrm{~g}), \mathrm{Cu}(0.36 \mathrm{~mL}$ of $25 \%$ $\mathrm{CuSO}_{4}$ solution), and $\mathrm{Se}\left(0.67 \mathrm{~g} \cdot \mathrm{L}^{-1}\right)$ at $380^{\circ} \mathrm{C}$ for $1 \mathrm{~h}$.
Potassium, $\mathrm{Mg}, \mathrm{Ca}$ and $\mathrm{B}$ were determined on the extracts via atomic absorption spectrophotometry. Nitrogen in the digest was determined through the formation of an ammoniumsalicylate complex and $\mathrm{P}$ was determined through the formation of a phosphomolybdenum blue complex (Technicon Autoanalyzer II Industrial Method No. 334-74A/A; Technicon, Elmsford, NY, USA).

Dormant spur flower buds (15 buds per tree) and current year's twigs were collected for total $\mathrm{N}$ measurements. Return bloom was determined the following spring on whole trees at the pink stage and expressed as the number of blossom clusters per $\mathrm{cm}^{2}$ TCSA.

\section{Statistical Analyses}

Data were subjected to an analysis of variance by the SAS GLM procedure (SAS Institute, Cary, N.C., USA). The blossom intensity determined before treatments was used as a covariate for the analysis of the effect on return bloom in the subsequent year, while fruit weight at harvest was used as a covariate for the analysis of the effect on fruit firmness and soluble solids.

\section{Results and Discussion}

\section{Vegetative Growth}

Shoot extension growth on vigorously growing top shoots and more horizontally growing side shoots were recorded at 7 to 10 days intervals throughout the summer. In both types of shoots, a single foliar spray of Pro-Ca at $250 \mathrm{mg} \cdot \mathrm{L}^{-1}$ markedly slowed down vegetative shoot growth within 14 days of treatment when applied 28 days AFB (Fig. 1). Until late August, Pro-Ca significantly decreased shoot growth of top and side shoots by $35 \%$ and $22 \%$, respectively. Water stress treatments also inhibited shoot growth but less markedly than Pro-Ca, while ethephon had no significant effect. A combined treatment of Pro-Ca and ethephon or water stress caused additional inhibition, and found to be most effective in inhibiting vegetative growth of top shoots. Some late season regrowth occurred on top shoots of Pro$\mathrm{Ca}$-treated trees. This growth reduction with Pro-Ca is consistent with other studies on spur 'Delicious' (Cline et al., 2008; Greene, 1999; Unrath, 1999), 'Fuji' (Byers et al., 2004; Unrath, 1999; Yoon and Sagong, 2005), 'Gala' (Byers and Yoder, 1999), 'Golden Delicious' (Ramirez et al., 2006; Yoder et al., 1999) and 'Mutsu' (Greene, 2008) apple trees.

Ethephon treatments did not effectively inhibit shoot extension growth when applied at $300 \mathrm{mg} \cdot \mathrm{L}^{-1}$ twice 35 and 71 AFB (Fig. 1). Final length of vigorously growing top shoots was not significantly different from the untreated control trees. In contrast, the higher rates of ethephon (1000 

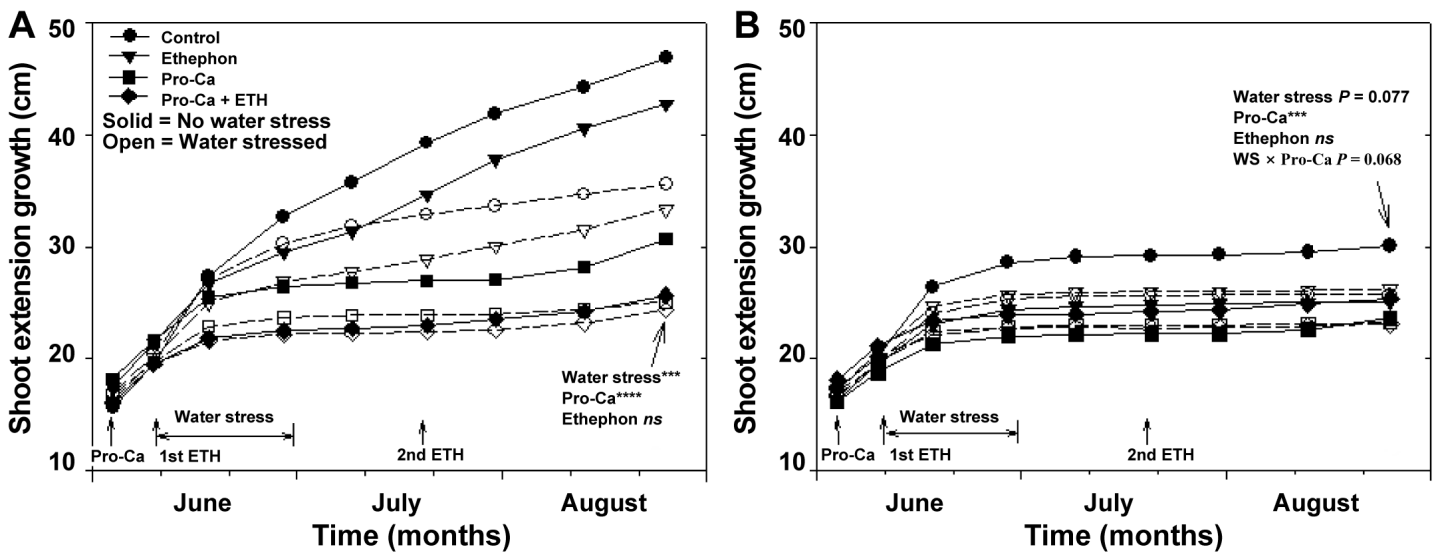

Fig. 1. Cumulative Shoot extension growth of slender-spindle 'Golden Delicious'/M.9 apple trees treated with Pro-Ca at $250 \mathrm{mg} \cdot \mathrm{L}^{-1}$, ethephon at $300 \mathrm{mg} \cdot \mathrm{L}^{-1}$ twice and water stress, measured from (A) vigorously growing top shoots and (B) more horizontally growing side shoots. Application times are shown in the figures.

to $1500 \mathrm{mg} \cdot \mathrm{L}^{-1}$ ) applied 12 to $26 \mathrm{AFB}$ not only substantially inhibited vegetative shoot growth but also reduced the fruit set in bearing 'Delicious' apple trees (Byers, 1993). In the current study, the insufficient growth reduction by ethephon could be due to our defensive decision on the application rate and timing in order to prevent its possible effect on fruit thinning. However, a combination of Pro-Ca plus ethephon was most effective in reducing terminal shoot growth (Fig. 1A). Elfving and Cline (1990) also showed that combination of daminozide plus ethephon effectively controlled vegetative shoot growth, increased flowering and cropping in apple trees at lower concentration of each material. In sweet cherry, a tank-mix of Pro-Ca at 125 to $250 \mathrm{mg} \cdot \mathrm{L}^{-1}$ plus ethephon $\left(175 \mathrm{mg} \cdot \mathrm{L}^{-1}\right)$ effectively reduced total shoot growth (Elfving et al., 2003). In grapes ethephon sprays at 420 to $720 \mathrm{mg} \cdot \mathrm{L}^{-1}$ after fruit set were most effective in controlling shoot extension growth when applied on freshly topped shoots (Shulman et al., 1980).

Mean leaf area and specific leaf weight were significantly reduced only by water stress ( $12.3 \%$ and $3.7 \%$, respectively) but unaffected by Pro-Ca or ethephon (Table 1). This result with Pro-Ca was inconsistent with that of our previous experiment using M.26 nursery liners potted in plastic containers, where Pro-Ca increased specific leaf weight

Table 1. Effects of Pro-Ca, ethephon, and water stress on fruit set, mean leaf area, and specific leaf weight of 'Golden Delicious' apple trees.

\begin{tabular}{|c|c|c|c|}
\hline $\begin{array}{l}\text { Pro-Ca/Ethephon } \\
\left(\mathrm{mg} \cdot \mathrm{L}^{-1}\right)\end{array}$ & $\begin{array}{c}\text { Fruit set } \\
(\%)^{z}\end{array}$ & $\begin{array}{l}\text { Mean leaf area } \\
\left(\mathrm{cm}^{2} / \text { leaf }\right)\end{array}$ & $\begin{array}{l}\text { Specific leaf weight } \\
\left(\mathrm{mg} \mathrm{DW} \cdot \mathrm{cm}^{-2}\right)\end{array}$ \\
\hline \multicolumn{4}{|c|}{ No water stress } \\
\hline $0 / 0$ & 56.4 & 31.5 & 14.4 \\
\hline $250 / 0$ & 52.9 & 30.0 & 14.8 \\
\hline 0/300 & 51.2 & 30.8 & 15.0 \\
\hline $250 / 300$ & 47.4 & 33.9 & 15.2 \\
\hline \multicolumn{4}{|c|}{ Water-stressed } \\
\hline $0 / 0$ & 39.4 & 30.0 & 14.2 \\
\hline $250 / 0$ & 43.8 & 26.2 & 14.5 \\
\hline 0/300 & 34.0 & 27.7 & 14.3 \\
\hline 250/300 & 39.9 & 26.8 & 14.3 \\
\hline \multicolumn{4}{|l|}{ Significance $^{y}$} \\
\hline Water stress & $* * *$ & ** & * \\
\hline Pro-Ca & NS & NS & NS \\
\hline Ethephon & NS & NS & NS \\
\hline
\end{tabular}

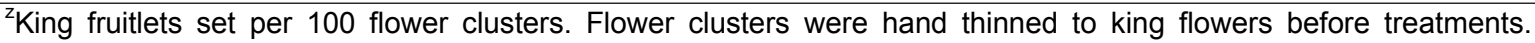
${ }^{y}$ No significant interactions between or among main factors were found.

$\mathrm{NS}^{*,+* *, * \star}$ Nonsignificant or significant at $P \leq 0.05,0.01$ or 0.001 , respectively. 

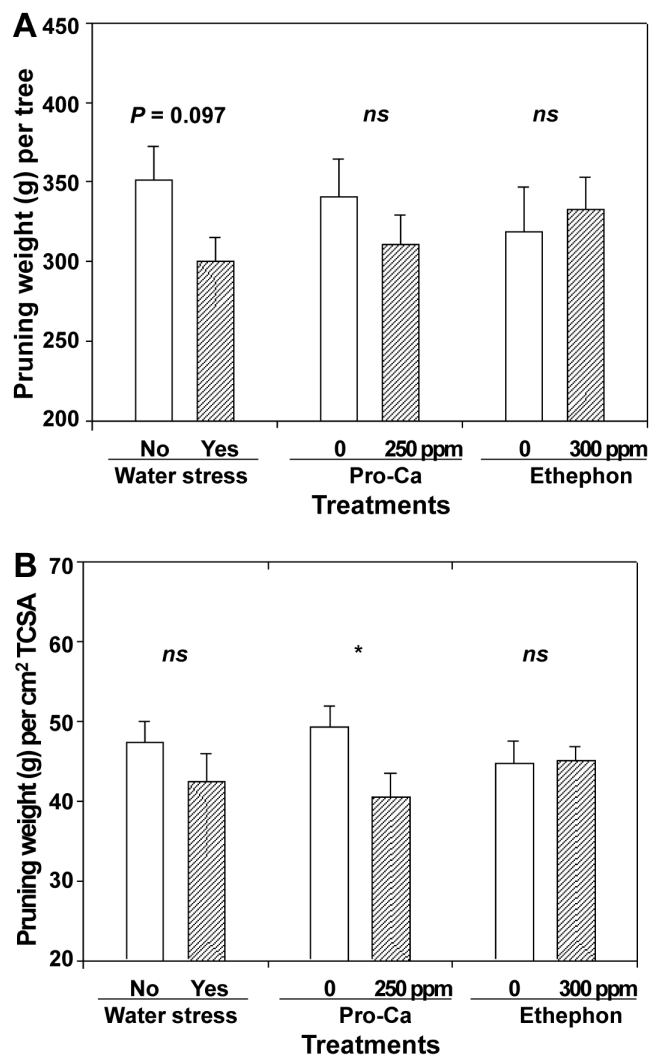

Fig. 2. Effects on winter pruning weight of 7-year-old slender spindle 'Golden Delicious' apple trees treated with Pro-Ca at $250 \mathrm{mg} \cdot \mathrm{L}^{-1} 32$ days $A F B$, ethephon at $300 \mathrm{mg} \cdot \mathrm{L}^{-1} 35$ and 71 days AFB and water stress for 3 weeks from 35 to 56 days $A F B$, expressed as pruning weight $(A)$ per tree and $(B)$ per $\mathrm{cm}^{2}$ TCSA. Each bar represents mean $\pm S D(n=20)$. proportionally to the rate in the range 125 to $250 \mathrm{mg} \cdot \mathrm{L}^{-1}$. This difference could be due to different plant materials used between two experiments. It is expected that bearing trees definitely have more sink capacity thus build up less amount of carbohydrates into the leaves than do nonbearing young trees. The reduction in vegetative growth by Pro-Ca led to a significant reduction in winter pruning weight per $\mathrm{cm}^{2}$ TCSA (Fig. 2). Water stress also seemed to reduce pruning weight per tree $(P=0.097)$. Addition of ethephon to Pro-Ca did not lead to a further reduction in pruning (data not shown).

\section{Fruit Set, Fruit Weight, and Yield}

Water stress significantly reduced the fruit set by $24.4 \%$, while Pro-Ca and ethephon had no effect (Table 1). Mean fruit weight at harvest was significantly reduced by water stress $(5.2 \%)$ and ethephon (10.5\%), while increased by Pro-Ca (6.5\%) (Table 2). Total fruit number per tree was significantly reduced by water stress, but unaffected by Pro-Ca and ethephon. Therefore water stress and ethephon treatments led to the reduction in fruit yield per tree by $17.9 \%$ and $21.3 \%$, respectively, but Pro-Ca did not significantly influence yield. As a general, Pro-Ca applications do not markedly affect fruit yield (Cline et al., 2008; Rademacher et al., 2004). In contrast, Costa et al. (2000) reported in 'Golden Delicious' apple trees that a single application of Pro-Ca at $175 \mathrm{mg} \cdot \mathrm{L}^{-1}$ increased both fruit size and yield. Rademacher et al. (2004) found a tendency for a slight yield increase in pear, depending on the cultivar and year.

Table 2. Effects of Pro-Ca, ethephon, and water stress on mean fruit weight, fruit number per tree, and fruit yield at harvest in 'Golden Delicious' apple trees.

\begin{tabular}{|c|c|c|c|c|}
\hline \multirow{2}{*}{$\begin{array}{l}\text { Pro-Ca/Ethephon } \\
\left(\mathrm{mg} \cdot \mathrm{L}^{-1}\right)\end{array}$} & \multirow{2}{*}{$\begin{array}{l}\text { Mean fruit wt. } \\
\text { (g) }\end{array}$} & \multirow{2}{*}{ Fruit no./tree } & \multicolumn{2}{|c|}{ Yield (kg) } \\
\hline & & & per tree & per $\mathrm{cm}^{2} \mathrm{TCSA}^{\mathrm{z}}$ \\
\hline \multicolumn{5}{|c|}{ No water stress } \\
\hline 0 & 180.9 & 52.9 & 9.1 & 1.35 \\
\hline $250 / 0$ & 185.3 & 52.0 & 9.4 & 1.20 \\
\hline $0 / 300$ & 153.7 & 44.7 & 6.2 & 0.85 \\
\hline $250 / 300$ & 171.4 & 42.5 & 7.3 & 0.93 \\
\hline \multicolumn{5}{|c|}{ Water-stressed } \\
\hline 0 & 162.9 & 46.8 & 7.2 & 1.12 \\
\hline $250 / 0$ & 182.3 & 38.6 & 6.9 & 1.04 \\
\hline $0 / 300$ & 154.1 & 45.8 & 6.2 & 0.93 \\
\hline $250 / 300$ & 157.8 & 42.2 & 6.0 & 0.83 \\
\hline \multicolumn{5}{|l|}{ Significance $^{y}$} \\
\hline Water stress (WS) & * & * & ** & $P=0.067$ \\
\hline Pro-Ca & * & NS & NS & NS \\
\hline Ethephon (ETH) & $* * * *$ & NS & $* * *$ & $* * * *$ \\
\hline WS $\times$ ETH & NS & * & $P=0.097$ & $P=0.098$ \\
\hline
\end{tabular}

${ }^{\mathrm{z}}$ TCSA, trunk cross-sectional area.

${ }^{\mathrm{y}}$ No other significant interactions between or among main factors were found.

NS,,,$+ * * * * * * * * *$ Nonsignificant or significant at $P \leq 0.05,0.01,0.001$ or 0.0001 , respectively. 
The results of our deficit irrigation treatment in 'Golden Delicious' apple are similar to those of previous studies that showed that deficit irrigation reduces fruit size and/or yield of apples, without loss of fruit quality at harvest and after storage (Caspari et al., 2004; Mpelasoka et al., 2000). It is expected that the timing of ending deficit irrigation may be a factor which can determine the level of potential negative effects of reduced supply of water on fruit size and yield. In addition, soil type may be considered before the optimal duration of deficit irrigation is decided. In this study, for example, it was found that the trees in the block of more sandy soil were more sensitive to the water deficit treatment, leading to more, earlier reduction of stomatal conductance than those in less sandy soil (data not shown).

The application timing of Pro-Ca may be critical to affecting fruit size. If Pro-Ca is applied during active period of cell division in the apple flesh, i.e. until 7 weeks after pollination (Denne, 1963), it may be reducing fruit size by slowing cell division via inhibiting gibberellin biosynthesis (Rademacher, 1991). In this study, Pro-Ca was applied 28 days AFB and, considering 10 to 14 days taken after application for Pro-Ca to start to be effective (Greene, 1999), the time Pro-Ca exerted its role, if any, on fruit cell expansion would be in the last phase of active cell expansion period. Therefore, it was not surprising to find that Pro-Ca did not show its typical negative effect on fruit size.

Some studies demonstrated little or no effect of Pro-Ca on fruit set in 'Gala' (Byers and Yoder, 1999), 'Mutsu' (Greene, 2008), and 'Empire' and 'Royal Court' apple trees (Cline et al., 2008). However, it is generally acknowledged that decreased fruit weight following Pro-Ca treatments is often associated with an increased fruit set in apple (Byers et al., 2004; Glenn and Miller, 2005; Greene, 1999; Ramirez et al., 2006). The lack of the Pro-Ca effect on fruit set in this study could result from flower thinning practice done before growth control treatments were made; all flower clusters were hand thinned to king flowers. Had it been not for thinning, fruit set would have been relatively increased on the Pro-Ca treated trees, compared to the untreated control trees where fruit set would be expected to be reduced by increased competitions between developing fruit and vegetative growth. Sugar et al. (2004) observed in 'Bartlett' pear that Pro-Ca reduced fruit size but this effect was not associated with fruit set.

\section{Fruit Quality and Mineral Nutrients}

A statistical analysis conducted using fruit size as a covariate showed that Pro-Ca decreased TA but had no effect on fruit shape, flesh firmness and SSC (Table 3). Water stress had no any effect on fruit quality attributes. Ethephon treatments significantly increased firmness, SSC and TA, but had no effect on fruit shape. Fruit size as a covariate significantly affected flesh firmness and SSC but did not influence fruit shape and TA. Fruit quality was also determined immediately

Table 3. Effects of Pro-Ca, ethephon, and water stress on fruit shape, firmness, SSC, and TA of 'Golden Delicious' apples at harvest.

\begin{tabular}{|c|c|c|c|c|}
\hline $\begin{array}{l}\text { Pro-Ca/Ethephon } \\
\left(\mathrm{mg} \cdot \mathrm{L}^{-1}\right)\end{array}$ & $\begin{array}{l}\text { Fruit shape } \\
\text { (L/D) }\end{array}$ & $\begin{array}{c}\text { Flesh firmness } \\
(\mathrm{N})\end{array}$ & $\begin{array}{l}\mathrm{SSC} \\
\left({ }^{\circ} \text { Brix }\right)\end{array}$ & $\mathrm{TA}^{\mathrm{z}}$ \\
\hline \multicolumn{5}{|c|}{ No water stress } \\
\hline 0 & 0.92 & 77.0 & 16.6 & 15.1 \\
\hline $250 / 0$ & 0.91 & 75.0 & 16.5 & 13.9 \\
\hline $0 / 300$ & 0.91 & 78.0 & 16.9 & 16.5 \\
\hline $250 / 300$ & 0.92 & 78.3 & 17.0 & 15.6 \\
\hline \multicolumn{5}{|c|}{ Water-stressed } \\
\hline 0 & 0.92 & 75.3 & 16.5 & 14.8 \\
\hline $250 / 0$ & 0.90 & 75.9 & 17.0 & 14.3 \\
\hline $0 / 300$ & 0.91 & 76.5 & 16.8 & 16.6 \\
\hline $250 / 300$ & 0.92 & 77.4 & 16.8 & 15.9 \\
\hline \multicolumn{5}{|l|}{ Significance $^{\mathrm{y}}$} \\
\hline Water stress & NS & NS & NS & NS \\
\hline Pro-Ca & NS & NS & NS & $* *$ \\
\hline Ethephon & NS & $P=0.085$ & NS & $* * * *$ \\
\hline Fruit wt. (covariate) & NS & $* * * *$ & $* * * *$ & NS \\
\hline
\end{tabular}

${ }^{\mathrm{z}} \mathrm{TA}$, titratable acidity, $\mathrm{mL}$ of $0.1 \mathrm{~N} \mathrm{NaOH}$ used to titrate $15 \mathrm{~mL}$ of extracted juice to $\mathrm{pH} 8.1$. ${ }^{\mathrm{y}}$ No significant interactions between or among main factors were found.

NS,${ }^{* * * * * *}$ Nonsignificant or significant at $P \leq 0.01$ or 0.0001 , respectively. 
after 120 days of cold storage as well as after 7 days of ripening at the room temperature. Regardless of treatments, after storage, fruit firmness and TA were readily decreased (11.6 and $38.1 \%$, respectively) but SSC was maintained at the level similar to that before storage, even though firmness, SSC and TA were maintained higher in the ethephon treatment than Pro-Ca or water stress treatment (data not shown). During 7 days of ripening, firmness and SSC were little changed but TA was dropped further (data not shown). Little information is available on the Pro-Ca effect on fruit quality in apple. Other studies showed little effects of Pro-Ca on fruit quality attributes in 'Fuji' (Mata et al., 2006; Yoon and Sagong, 2005) and 'Gala' (Mata et al., 2006) apple.

Fruit mineral nutrient concentrations were influenced by growth regulators and water stress treatments (Table 4). Pro-Ca significantly increased fruit $\mathrm{N}, \mathrm{K}$, and $\mathrm{Mg}$ concentrations, ethephon increased $\mathrm{N}, \mathrm{P}, \mathrm{K}, \mathrm{Mg}$, and $\mathrm{B}$, and water stress increased $\mathrm{K}$ and $\mathrm{B}$. Fruit $\mathrm{Ca}$ concentration was not influenced by any treatments. Higher concentrations of fruit minerals in the ethephon-treated trees could be related to a smaller fruit size but those in the Pro-Ca treated trees cannot be explained that way, since there was no reduction in fruit size by Pro-Ca. A possible explanation for the Pro-Ca effect would be that reduction in shoot growth by Pro-Ca caused trees to divert relatively more minerals to fruits and/or stimulated the growth of roots which resulted in more uptakes of minerals. In our previous experiment with apple nursery plants, Pro-Ca substantially reduced shoot growth but increased root growth, which led to the increased root to shoot ratio, whereas $\mathrm{GA}_{4+7}$ applied to the Pro-Ca treated trees one day later apparently reversed the Pro-Ca effect (Guak et al., 2001). Elfving and Cline (1990) reported that growth control treatments such as daminozide and ethephon had no direct effect on foliar or fruit macronutrient concentrations in 'Northern Spy'/MM.106 apple trees.

\section{Leaf Water Potential and Stomatal Conductance}

Three weeks of water stress significantly reduced mid-day leaf water potential about $18 \%$ from $-1.66 \mathrm{MPa}$ to -2.03 $\mathrm{MPa}$ and stomatal conductance about 38\% from 205.0 to $127.8 \mathrm{mmol} \cdot \mathrm{m}^{-2} \cdot \mathrm{s}^{-1}$ (Fig. 3). Nine days after rewatering, leaf water potential in water-stressed trees was recovered to the level similar to that of the unstressed control trees. However, stomatal conductance remained still lower on water-stressed tree leaves $(P<0.001)$, indicating an 'after effect' of water stress on stomata present even after recovery of leaf water potential (Fischer, 1970). It was interesting to observe that during water stress period stomatal conductance was slightly decreased in the ethephon treatment than Pro-Ca or untreated control $(P<0.05)$. These ethephon-induced higher values in stomatal conductance were also observed 7 days after rewatering $(P<0.05)$. This positive effect of ethephon on the maintenance of higher stomatal conductance during stress conditions or post stress period could be due to the inhibitive effect of ethephon on ABA-induced stomatal closure (Tanaka et al., 2005). ABA, synthesized in response to drought stress, is known to induce stomatal closure and to reduce transpirational water loss in plants (Schroeder et al., 2001).

Table 4. Fruit mineral nutrients at harvest in 'Golden Delicious' apple trees treated with Pro-Ca, ethephon, and water stress.

\begin{tabular}{|c|c|c|c|c|c|c|}
\hline \multirow{2}{*}{$\begin{array}{l}\text { Pro-Ca/Ethephon } \\
\left(\mathrm{mg} \cdot \mathrm{L}^{-1}\right)\end{array}$} & \multicolumn{6}{|c|}{ Fruit nutrients (mg.100 $\left.\mathrm{g}^{-1} \mathrm{FW}\right)$} \\
\hline & $\mathrm{N}$ & $\mathrm{P}$ & $\mathrm{K}$ & $\mathrm{Ca}$ & $\mathrm{Mg}$ & $\mathrm{B}$ \\
\hline \multicolumn{7}{|c|}{ No water stress } \\
\hline 0 & 46.2 & 13.7 & 130.6 & 4.2 & 5.9 & 0.14 \\
\hline $250 / 0$ & 53.9 & 14.0 & 136.4 & 4.0 & 6.0 & 0.18 \\
\hline $0 / 300$ & 57.5 & 15.1 & 148.8 & 3.6 & 6.2 & 0.18 \\
\hline $250 / 300$ & 60.3 & 15.6 & 146.0 & 4.1 & 6.6 & 0.19 \\
\hline \multicolumn{7}{|c|}{ Water-stressed } \\
\hline 0 & 47.9 & 13.7 & 137.4 & 4.2 & 5.9 & 0.18 \\
\hline $250 / 0$ & 50.6 & 14.4 & 150.2 & 3.9 & 6.3 & 0.19 \\
\hline $0 / 300$ & 51.2 & 14.8 & 145.2 & 4.2 & 6.4 & 0.23 \\
\hline $250 / 300$ & 56.5 & 14.7 & 152.9 & 4.1 & 6.5 & 0.21 \\
\hline \multicolumn{7}{|l|}{ Significance $^{z}$} \\
\hline Water stress & NS & NS & * & NS & NS & $* *$ \\
\hline Pro-Ca & * & NS & * & NS & * & NS \\
\hline Ethephon & $* *$ & * & $* *$ & NS & $* * *$ & * \\
\hline
\end{tabular}

${ }^{\mathrm{z}}$ No significant interactions between or among main factors were found.

NS, ${ }^{*,+*},{ }^{* \star *}$ Nonsignificant or significant at $P \leq 0.05,0.01$, or 0.001 , respectively. 

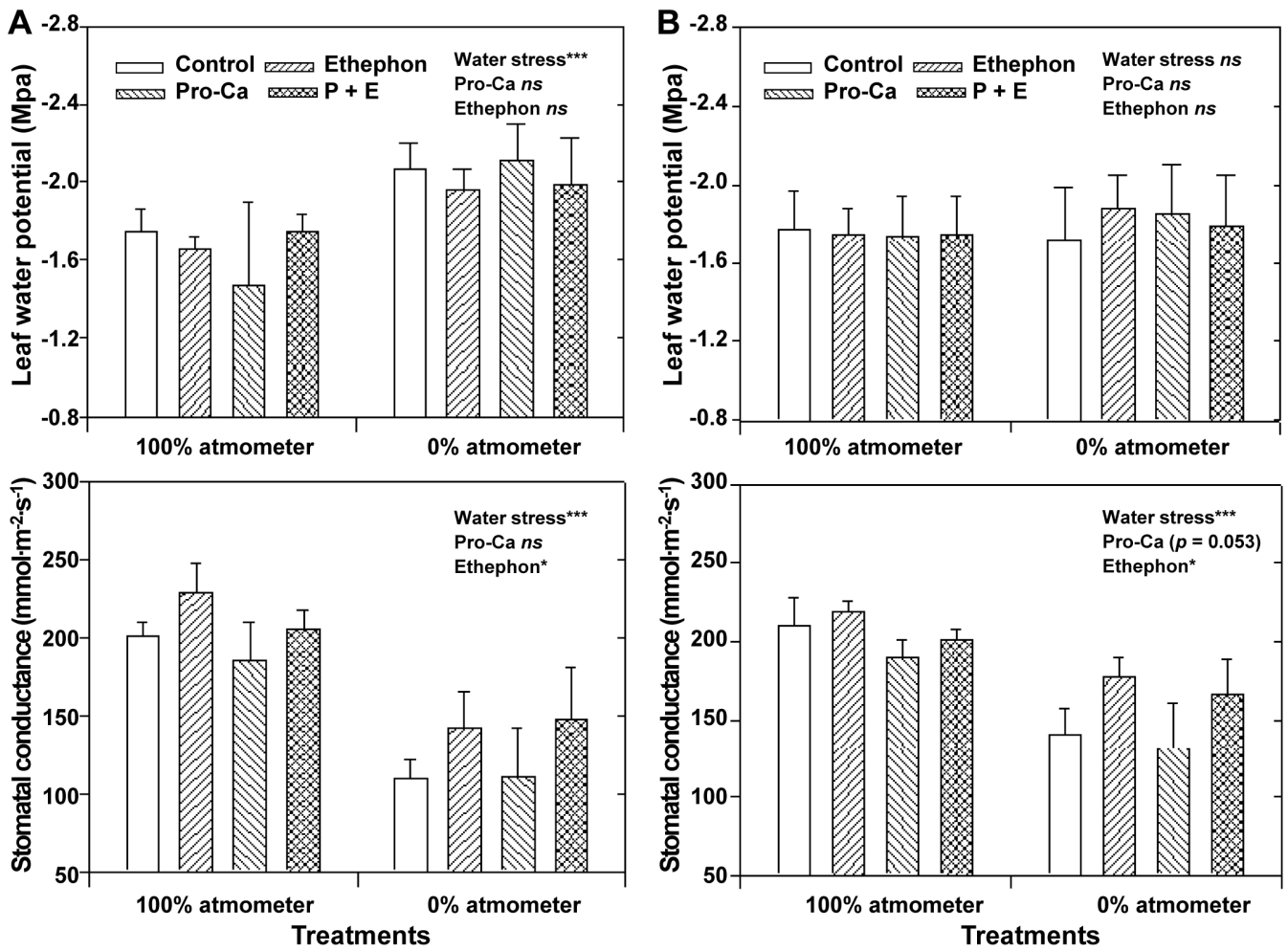

Fig. 3. Mid-day leaf water potential and stomatal conductance measured on the last day of water stress period (A) and 9 days after rewatering (B) in 'Golden Delicious' apple trees treated with water stress for 3 weeks with $0 \%$ atmometer, Pro-Ca at 250 $\mathrm{mg} \cdot \mathrm{L}^{-1}$ and ethephon at $300 \mathrm{mg} \cdot \mathrm{L}^{-1}$. Each bar represents \pm mean $\mathrm{SD}(\mathrm{n}=5)$. No significant interactions between or among factors were found.

Unfortunately, soil water content was not measured in this study. During water stress period, the experimental site received moderate rain shower twice. That was a reason the water stress period was extended up to 3 weeks until noticeable effect of water stress on stomatal conductance and water potential was detected. Therefore, this length of water stress for controlling vegetative growth may be harmful to the trees growing under different conditions.

\section{Dormant Spur Bud Size, Bud Total-N, and Spring Growth}

Dormant spur buds were slightly but significantly reduced in their dry weight by Pro-Ca and water stress (Table 5). This result was contradictory to our expectation that reducing vegetative growth would enhance the size and development of flower buds. One of the possibilities to explain the difference could be that on the dwarf trees Pro-Ca or water stress reduces the leaf to fruit ratio (unless fruit number is properly adjusted) enough to limit the photoassimilates available for flower bud development. This may be compared to the vigorous trees where even after application of a growth retardant a sufficient amount of foliage can still be maintained enough to supply both fruit and flower buds with sufficient amount of photoassimilates for normal development. In this experiment, Pro-Ca reduced foliage by decreasing leaf number (data not shown), and water stress reduced it by decreasing both leaf number (data not shown) and size (Table 1). Water stress also reduced stomatal conductance (Fig. 3), which could reduce the photosynthetic rate. Our previous study with M.26 nursery trees showed that Pro-Ca reduced the formation of new leaves by $25 \%$ (Guak et al., 2001). Other possibility of the negative effect of Pro-Ca on bud size could be due to abnormal flower bud development by Pro-Ca, as suggested by Deckers and Schoofs (2004) who reported in 'Conference' pear trees that high rates of Pro-Ca can result in flower buds without leaves.

In contrast, ethephon significantly increased mean dry weight of dormant spur buds especially on the trees grown under no water-stressed conditions (Table 5). A significant reduction in fruit size by ethephon (Table 2) might have caused trees to divert some carbohydrates to the buds.

Total $\mathrm{N}$ concentrations of the dormant spur flower buds were increased by all treatments, while those of twig total $\mathrm{N}$ were unaffected (Table 5). Increases in bud $\mathrm{N}$ by Pro-Ca or water stress treatment were possibly due to the concentration effect via bud size reduction. With the ethephon treatment, however, the reason for that increase was unclear. Relatively larger size and higher $\mathrm{N}$ content (mean bud weight $\times \mathrm{N}$ concentration) of the dormant buds resulted in larger spur 
flowers at the tight cluster stage the following season (Figs. $4 \mathrm{~A}$ and $4 \mathrm{~B} ; \mathrm{r}^{2}=0.78$ and 0.70 , respectively). However, there was no relationship between bud total $\mathrm{N}$ concentration and flower weight (Fig. 4C).

\section{Return Bloom}

Double sprays of ethephon significantly promoted flowering the following season mainly by increasing lateral flowers on previous season's shoots, not on spurs, while Pro-Ca or water stress treatment did not show any significant effect (Table 6). Pro-Ca seemed to inhibit subsequent flowering

Table 5. Effects of Pro-Ca, ethephon, and water stress on mean spur bud weight and total $\mathrm{N}$ concentrations in dormant buds and twigs of 'Golden Delicious' apple trees, determined in early December.

\begin{tabular}{|c|c|c|c|}
\hline \multirow{2}{*}{$\begin{array}{l}\text { Pro-Ca/Ethephon } \\
\left(\mathrm{mg} \cdot \mathrm{L}^{-1}\right)\end{array}$} & \multirow{2}{*}{ 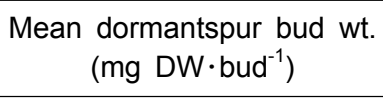 } & \multicolumn{2}{|c|}{ Total N (\% DW) in dormant tissues } \\
\hline & & Spur buds & Twigs \\
\hline \multicolumn{4}{|c|}{ No water stress } \\
\hline 0 & 34.5 & 1.38 & 0.91 \\
\hline $250 / 0$ & 32.6 & 1.49 & 1.06 \\
\hline $0 / 300$ & 39.2 & 1.50 & 1.06 \\
\hline $250 / 300$ & 35.9 & 1.48 & 0.98 \\
\hline \multicolumn{4}{|c|}{ Water-stressed } \\
\hline 0 & 34.1 & 1.44 & 0.97 \\
\hline $250 / 0$ & 29.3 & 1.46 & 0.97 \\
\hline $0 / 300$ & 33.7 & 1.54 & 1.11 \\
\hline $250 / 300$ & 31.1 & 1.70 & 1.15 \\
\hline \multicolumn{4}{|l|}{ Significance $^{z}$} \\
\hline Water stress & $* * *$ & * & NS \\
\hline Pro-Ca & $* *$ & * & NS \\
\hline Ethephon & ** & * & NS \\
\hline
\end{tabular}

${ }^{z}$ No significant interactions between or among main factors were found.

$\mathrm{NS}_{, *, * * * \star * \star}$ Nonsignificant or significant at $P \leq 0.05,0.01$ or 0.001 , respectively.

Table 6. Return bloom of 7-year-old slender spindle 'Golden Delicious' apple trees treated with Pro-Ca, ethephon, and water stress.

\begin{tabular}{|c|c|c|c|c|}
\hline \multirow{2}{*}{$\begin{array}{l}\text { Pro-Ca/Ethephon } \\
\left(\mathrm{mg} \cdot \mathrm{L}^{-1}\right)\end{array}$} & \multirow{2}{*}{$\begin{array}{c}\text { Pretreatment bloom extent } \\
\text { (No. flower clusters } / \mathrm{cm}^{2} \text { LCSA) }\end{array}$} & \multicolumn{3}{|c|}{$\begin{array}{c}\text { Return bloom } \\
\text { (No. flower clusters } / \mathrm{cm}^{2} \text { LCSA }^{z} \text { ) on: }\end{array}$} \\
\hline & & 1-year shoots & Spurs & Total \\
\hline \multicolumn{5}{|c|}{ No water stress } \\
\hline 0 & 28.10 & 29.8 & 23.1 & 52.9 \\
\hline $250 / 0$ & 34.70 & 22.9 & 23.7 & 46.6 \\
\hline $0 / 300$ & 30.40 & 35.5 & 26.5 & 62.0 \\
\hline $250 / 300$ & 29.70 & 31.2 & 18.8 & 50.0 \\
\hline \multicolumn{5}{|c|}{ Water-stressed } \\
\hline 0 & 32.40 & 26.8 & 26.3 & 53.1 \\
\hline $250 / 0$ & 28.90 & 22.2 & 20.0 & 42.2 \\
\hline $0 / 300$ & 36.70 & 32.5 & 23.0 & 55.5 \\
\hline $250 / 300$ & 34.90 & 31.4 & 30.0 & 61.4 \\
\hline \multicolumn{5}{|l|}{ Significance $^{y}$} \\
\hline Water stress & - & NS & NS & NS \\
\hline Pro-Ca & - & NS & NS & NS \\
\hline Ethephon & - & $* * *$ & NS & * \\
\hline
\end{tabular}

${ }^{\mathrm{z}}$ LCSA, limb cross-sectional area.

${ }^{\mathrm{y}}$ No significant interactions between or among main factors were found.

NS, ${ }^{* * * *}$ Nonsignificant or significant at $P \leq 0.05$ or 0.001 , respectively. 


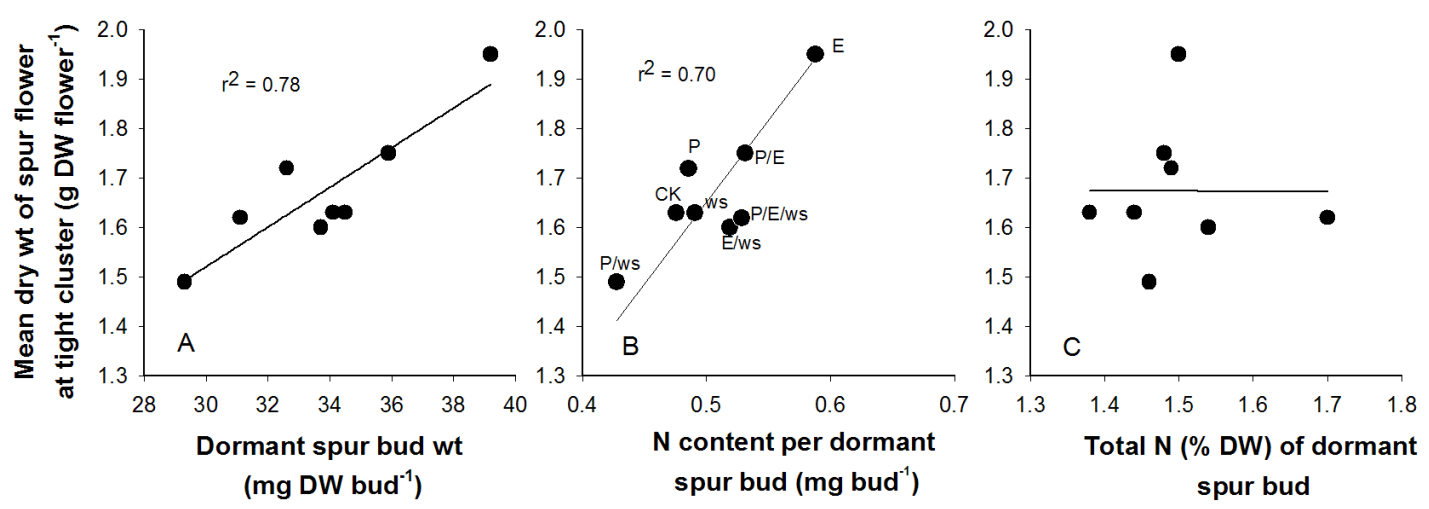

Fig. 4. Relationships between mean dry weight of spur flowers at the tight cluster stage and (A) dry weight of mean dormant spur buds or (B) N content per dormant spur bud or (C) total N concentrations of dormant spur bud in 'Golden Delicious' apple trees treated with Pro-Ca at $250 \mathrm{mg} \cdot \mathrm{L}^{-1}$, ethephon at $300 \mathrm{mg} \cdot \mathrm{L}^{-1}$ and water stress. In (B), CK, control with no water stress; P, Pro-Ca; E, ethephon; and ws, water-stressed.

on 1-year-old shoots but this effect would be diminished when supplemented with ethephon.

Ethephon is well-known to increase return flowering in apple (Byers, 1993) and sweet cherry (Elfving et al., 2003; Facteau and Rowe, 1979). Byers (1993) reported that early season applications of ethephon at $500-1500 \mathrm{mg} \cdot \mathrm{L}^{-1}$ greatly increased return flowering in spur 'Delicious' apples but also caused fruit abscission. Elfving et al. (2003) noted in young, vigorous sweet cherry trees that double tank-mix applications of Pro-Ca at $125 \mathrm{mg} \cdot \mathrm{L}^{-1}$ and ethephon at $150 \mathrm{mg} \cdot \mathrm{L}^{-1}$ substantially increased subsequent flowering on both previous season's shoots and spurs on older wood nearly three-fold.

Inhibitors of GA biosynthesis have shown variable flowering responses of apple trees, ranging from slight depressions in flowering and yield (Edgerton, 1986; Greene, 2008) to significant increases of both flowering and total yield (Elfving and Cline, 1990; Owens and Stover, 1999). Flowering responses to Pro-Ca seemed to be dependent on the time and rate of application or cultivar. Owens and Stover (1999) observed that Pro-Ca treatment applied in August significantly increased flowering in 'Macoun' apple compared to the earlier or later applications, while 'Delicious' and 'Fuji' did not respond to. Greene (2008) found in 'Mutsu' apples that low rates of Pro-Ca at $42-84 \mathrm{mg} \cdot \mathrm{L}^{-1}$ had no effect on return bloom, while high rates at $500-1000 \mathrm{mg} \cdot \mathrm{L}^{-1}$, especially those intended to retard fire blight, reduced return bloom. In 'Bosc', 'Bartlett' and 'Anjou' pear trees, return bloom was reduced when treated with multiple doses of Pro-Ca at $83-125 \mathrm{mg} \cdot \mathrm{L}^{-1}$ (Sugar et al., 2004). Rademacher et al. (2004) pointed out that too high dosages particularly in pear trees may lead to reductions in return bloom. Our previous study with 'Lapins'Mazzard sweet cherry trees showed that Pro-Ca had no effect on return flowering when treated at $125-250 \mathrm{mg} \cdot \mathrm{L}^{-1}$ at various timings (Guak et al., 2005). A similar result was reported by Elfving et al. (2003) who observed that growth inhibition by Pro-Ca alone did not improve flowering in young, vigorous 'Bing'/Mazzard sweet cherry trees.

\section{Conclusions}

In conclusion, as a tool to control vegetative growth in apple, Pro-Ca, ethephon and water stress treatment alone and in combination were evaluated in 'Golden Delicious' /M.9 apple trees. In this high density planting, only Pro-Ca proved effective as a growth control agent without reducing fruit size and yield, with its effect being noticeable within 14 days of treatment. Pro-Ca had no effects on fruit set but slightly increased fruit size. Pro-Ca increased fruit N, K, and $\mathrm{Mg}$, and decreased TA. Pro-Ca reduced dormant spur bud weight, which could be due to delayed flower bud development or to reduced foliage and thus limited photoassimilates for normal bud development. Perhaps for the same reasons, Pro-Ca failed to promote return flowering. Ethephon alone, although not effective in controlling shoot growth, stimulated flower formation especially on previous season's shoots and also probably relieved such negative effect of Pro-Ca on flowering. Using more various application rates, a further study should be required to figure out the optimum combination of Pro-Ca and ethephon for controlling vegetative growth and also promoting flowering especially for young, vigorous apple trees. As a general, water stress or ethephon treatment had no influence on the efficacy of Pro-Ca on most variables observed in this study. It is expected that under the weather conditions that facilitate vegetative growth of apple trees, such as during the monsoon season in Korea, applications of Pro-Ca may be useful in suppressing excessive growth of new shoots, more potentially in concert with ethephon. 


\section{Literature Cited}

Basak, A. 2004. Growth and fruiting of 'Elstar' apple trees in response to prohexadione calcium depending on the rootstock. Acta Hort. 653:117-125.

Byers, R.E. 1993. Controlling growth of bearing apple trees with ethephon. HortScience 28:1103-1105.

Byers, R.E., D.H. Carbaugh, and L.D. Combs. 2004. The influence of prohexadione-calcium sprays on apple tree growth, chemical thinning, and return bloom. J. Amer. Pomol. Soc. 58:111-117.

Byers, R.E. and K.S. Yoder. 1999. Prohexadione-calcium inhibits apple, but not peach, tree growth, but has little influence on apple fruit thinning or quality. HortScience 34:1205-1209.

Caspari, H.W., S. Neal, and P. Alspach. 2004. Partial rootzone drying. A new deficit irrigation strategy for apple. Acta Hort. 646:93-100.

Cline, J.A., C.G. Embree, J. Hebb, and D.S. Nichols. 2008. Performance of prohexadione-calcium on shoot growth and fruit quality of apple - Effect of spray surfactants. Can. J. Plant Sci. 88:165-174.

Costa. G., E. Sabatini, F. Spinelli, C. Andreotti, C. Bomben, and G. Vizzotto. 2004. Two years of application of prohexadione$\mathrm{Ca}$ on apple: Effect on vegetative and cropping performance, fruit quality, return bloom and residual effect. Acta Hort. 653:35-40.

Deckers, T. and H. Schoofs. 2004. Growth reduction and flower bud quality on pear trees. Acta Hort. 636:249-258.

Denne, M.P. 1963. Fruit development and some tree factors affecting it. N. Z. J. Bot. 1:265-294.

Dry, P.R. and B.R. Loveys. 1998. Factors influencing grapevine vigour and the potential for control with partial rootzone drying. Aust. J. Grape Wine Res. 4:140-148.

Ebel, R.C., E.L. Proebsting, and R.G. Evans. 1995. Deficit irrigation to control vegetative growth in apple and monitoring fruit growth to schedule irrigation. HortScience 30:1229-1232.

Edgerton, L.J. 1986. Some effects of paclobutrazol on growth and fruiting of apple, peach, and cherry. Acta Hort. 179:467-472.

Edgerton, L.J. and W.J. Greenhalgh. 1969. Regulation of growth, flowering and fruit abscission with 2-chloroethanephosphonic acid. J. Amer. Soc. Hort. Sci. 94:11-13.

Elfving, D.C. and R.A. Cline. 1990. Growth and productivity of vigorous 'Northern Spy'/MM.106 apple trees in response to annually applied growth control techniques. J. Amer. Soc. Hort. Sci. 115:212-218.

Elfving, D.C., G.A. Lang, and D.B. Visser. 2003. Prohexadione$\mathrm{Ca}$ and ethephon reduce shoot growth and increase flowering in young, vigorous sweet cherry trees. HortScience 38:293-298.

Facteau, T.J. and K.E. Rowe. 1979. Growth, flowering and fruit set responses of sweet cherries to daminozide and ethephon. HortScience 14:234-236.

Fischer, R.A. 1970. After-effect of water stress on stomatal opening potential: II. Possible causes. J. Exp. Bot. 21:386-404.

Glenn, D.M. and S.S. Miller. 2005. Effects of Apogee on growth and whole-canopy photosynthesis in spur 'Delicious' apple trees. HortScience 40:397-400.
Greene, D.W. 1986. Effect of paclobutrazol and analogs on growth, yield, fruit quality, and storage potential of 'Delicious' apples. J. Amer. Soc. Hort. Sci. 111:328-332.

Greene, D.W. 1999. Tree growth management and fruit quality of apple trees treated with prohexadione-calcium (BAS 125). HortScience 34:1209-1212.

Greene, D.W. 2008. The effect of repeat annual applications of prohexadione-calcium on fruit set, return bloom, and fruit size of apples. HortScience 43:376-379.

Guak, S., D. Neilsen, and N.E. Looney. 2001. Growth, allocation of $\mathrm{N}$ and carbohydrates, and stomatal conductance of greenhouse grown apple treated with prohexadione-Ca and gibberellins. J. Hort. Sci. Biotech. 76:746-752.

Guak, S., M. Beulah, and N.E. Looney. 2005. Controlling growth of sweet cherry trees with prohexadione-calcium: Its effect on cropping and fruit quality. Acta Hort. 667:433-437.

Lord, W.J., D.W. Greene, and R.A. Damon, Jr. 1975. Evaluation of fruit abscission and flower bud promotion capabilities of ethephon and SADH on apples. J. Amer. Soc. Hort. Sci. 100:259-261.

Mata, A.P., J. Val and A. Blanco. 2006. Differential effects of prohexadione-calcium on red color development in 'Royal Gala' and 'Fuji' apples J. Hort. Sci. Biotech. 81:84-88.

Mpelasoka, B.S., M.H. Behboudian, J. Dixon, S.M. Neal, and H.W. Caspari. 2000. Improvement of fruit quality and storage potential of 'Braeburn' apple through deficit irrigation. J. Hort. Sci. Biotech. 75:615-621.

Miller, S.S. 2002. Prohexadione-calcium controls vegetative growth in apple. J. Tree Fruit Prod. 3:11-28.

Owens, C.L. and E. Stover. 1999. Vegetative growth and flowering of young apple trees in response to prohexadione-calcium. HortScience 34:1194-1196.

Quinlan, J.D. and P.J. Richardson. 1984. Effect of paclobutrazol (PP333) on apple shoot growth. Acta Hort. 146:105-111.

Rademacher, W. 1991. Inhibitors of gibberellin biosynthesis: Applications in agriculture and horticulture, p. 296-310. In: N. Takahashi, B.O. Phinney, and J. MacMillan (eds.) Gibberellins. Springer-Verlag, New York.

Rademacher, W. and R. Kober. 2003. Efficient use of prohexadione$\mathrm{Ca}$ in pome fruits. Europ. J. Hort. Sci. 68:101-107.

Rademacher, W., K. van Saarloos, J.A. Garuz Porte, F. Riera Forcades, Y. Senechal, C. Andreotti, F. Spinelli, E. Sabatini, and G. Costa. 2004. Impact of prohexadione-Ca on the vegetative and reproductive growth of apple and pear trees. Europ. J. Hort. Sci. 69:221-228.

Ramirez, H., S. Alonso, and A. Benavides. 2006. Prohexadione$\mathrm{Ca}$ modifies growth and endogenous hormones in the shoot apex in apple trees. Acta Hort. 727:117-123.

Schroeder, J.I., G.J. Allen, V. Hugouvieux, J.M. Kwak, and D. Waner. 2001. Guard cell signal transduction. Annu. Rev. Plant Physiol. Plant Mol. Biol. 52:627-658.

Shulman, Y., G. Hirschfeld, and S. Larvee. 1980. Vegetative growth control of six grapevine cultivars by spray application of (2-chloroethyl) phosphonic acid (ethephon). Amer. J. Enol. Vitic. 31:288-293.

Steffens, G.L., J.T. Lin, A.E. Stafford, J.D. Metzger, and J.P. Hezebroek. 1992. Gibberellin content of immature apple 
seeds from paclobutrazol treated trees over three seasons. J. Plant Growth Regul. 11:165-170.

Sugar, D., D.C. Elfving, and E.A. Mielke. 2004. Effects of prohexadione-calcium on fruit size and return bloom in pear. HortScience 39:1305-1308.

Tanaka,Y., T. Sano, M. Tamaoki, N. Nakajima, N. Kondo, and S. Hasezawa. 2005. Ethylene inhibits abscisic acid-induced stomatal closure in Arabidopsis. Plant Physiol. 138:2337-2343. Unrath, C.R. 1999. Prohexadione-Ca: A promising chemical for controlling vegetative growth of apples. HortScience 34:1197 -1200 .

Yoon, T.M. and D.H. Sagong. 2005. Growth control of 'Fuji' apple trees by use of prohexadione-calcium. Kor. J. Hort. Sci. Technol. 23:269-274. 